\title{
Ancoragem esquelética no início do século XXI
}

Arquimedes (287a.C. - 212a.C.), físico, matemático e inventor grego, teve grande importância em várias áreas do conhecimento da ciência moderna. No campo da Física, descobriu o princípio da alavanca e a ele é atribuída a frase: "Dêem-me uma alavanca e um ponto de apoio e eu moverei o mundo". Um ponto de apoio firme é o que o ortodontista mais deseja, para ancorar com segurança e efetuar os movimentos dentários planejados.

Por sua vez, Edward Hartley Angle, em 1907, nos ensinou que a ancoragem pode ser simples, estacionária, recíproca, intermaxilar e occiptal. Em seus escritos sobre o assunto, reverenciou Isaac Newton, cujo nascimento, em 25 de dezembro de 1642, no calendário juliano, foi um presente para humanidade. Sua terceira lei - "a toda ação há sempre uma reação igual e em sentido contrário" - está presente no dia-a-dia dos ortodontistas. Embora, no movimento dentário ortodôntico, tipicamente, a ação das forças seja desejada, a reação pode não ser e, nestes casos, o advento da ancoragem esquelética descortinou novos horizontes terapêuticos. Com a utilização de miniplacas e mini-implantes, pode-se realizar, com segurança, por vezes sem efeitos colaterais indesejáveis, movimentos dentários nos planos vertical, transverso e ântero-posterior.

Todavia, ainda que a ancoragem esquelética esteja fixada como uma alternativa de tratamento da Ortodontia moderna, há muito espaço para a ampliação de seu emprego. Novas terapias surgem continuamente e tendem a proporcionar melhores resultados de tratamento, à medida que as evidências se tornam mais sólidas.
Ao mesmo tempo, uma restrição ao desenvolvimento dessas terapias, possivelmente, advém da tendência de inserção da ancoragem esquelética nos esquemas tradicionais de tratamento. Os aparelhos ortodônticos existentes foram desenvolvidos, ao longo dos anos, para uma mecânica ortodôntica convencional e a tarefa de torná-los funcionais, quando associados à ancoragem esquelética, é desafiadora.

Outro fator que enevoa a visão das atuais e futuras aplicações da ancoragem esquelética é a tendência de inferir possíveis resultados de tratamento a partir daqueles já conhecidos nas terapias tradicionais. E - para adicionar ainda mais complexidade ao problema, ao mesmo tempo - não podemos nos esquecer dos fundamentos ortodônticos já estabelecidos e essenciais para o aprendizado e a prática ortodôntica.

Essas dificuldades serão dirimidas com o tempo, por meio de publicações sobre o assunto, até o ponto em que fortes evidências se construam sobre as hipóteses testadas.

A intenção de tornar mais claros alguns dos avanços recentes nesse campo nos motivou a organizar um número especial comemorativo dos 12 anos da Revista Dental Press de Ortodontia e Ortopedia Facial totalmente voltado para esse tema. Ele transporta experiência clínica e conhecimento científico de Dr. Kyung e de renomados autores brasileiros. Estamos certos de que sua leitura será profícua para todos.

Jorge Faber

Telma Martins de Araújo

Editores 